\title{
Do We Ignore Tobacco's Positive Ecological Role Too Long?
}

\author{
Shaomin Yan, Guang Wu \\ National Engineering Research Center for Non-Food Biorefinery, State Key Laboratory of Non-Food Biomass and \\ Enzyme Technology, Guangxi Key Laboratory of Bio-Refinery, Guangxi Biomass Engineering Technology Research \\ Center, Guangxi Academy of Sciences, Nanning, China
}

Correspondence to: Guang Wu, hongguanglishibahao@gxas.cn

Keywords: Air Pollution, Nitrogen Oxides, $\mathrm{PM}_{2.5}$, Phytoremediation, Tobacco

Received: March 25, $2020 \quad$ Accepted: May 11, $2020 \quad$ Published: May 14, 2020

Copyright $\odot 2020$ by author(s) and Scientific Research Publishing Inc.

This work is licensed under the Creative Commons Attribution International License (CC BY 4.0).

http://creativecommons.org/licenses/by/4.0/

\section{(c) (i) Open Access}

\section{ABSTRACT}

Definitely, tobacco is one of the most troubling plants in this planet because of its harmful effects on humans. Therefore, tobacco plantation declines continuously in the world. For such a plant, do we need to eliminate tobacco entirely from the surface of the earth? Perhaps, humans might have ignored the tobacco's positive role in environment and ecology, especially in the heavily industrialized environments, for too long. Because the human activity generates more and more nitrogen oxides $\left(\mathrm{NO}_{\mathrm{x}}\right)$ in atmosphere, which not only cause imbalance in the global nitrogen cycle but also lead to haze, smog, acid rain, $\mathrm{PM}_{2.5}$, and eventually impact on environment and human health. Unfortunately the current technologies do not provide an efficient way to remove $\mathrm{NO}_{\mathrm{x}}$ from atmosphere. However, it is only tobacco can remove $\mathrm{NO}_{\mathrm{x}}$ from atmosphere. Perhaps, we should blame us, humans who use tobacco unwisely, rather than blame tobacco in nature. Anyways, the ability of tobacco to remove $\mathrm{NO}_{2}$ from atmosphere should not be ignored.

\section{NITROGEN OXIDES AND THEIR EFFECTS IN ENVIRONMENT}

Nitrogen is one of the most abundant elements in the earth, and accounts for $78.1 \%$ of the atmosphere. Being an inert gas, nitrogen can be used by organisms only when it is converted into reactive nitrogen [1], although it is essential for all the living species. There are various forms of reactive nitrogen $(\mathrm{Nr})$ in the atmosphere: ammonia $\left(\mathrm{NH}_{3}\right)$, nitrous oxide $\left(\mathrm{N}_{2} \mathrm{O}\right)$, nitric acid $\left(\mathrm{HNO}_{3}\right)$, nitrous acid $(\mathrm{HONO})$, nitrogen oxide $\left(\mathrm{NO}_{\mathrm{x}}\right)$ including nitric oxide $(\mathrm{NO})$ and nitrogen dioxide $\left(\mathrm{NO}_{2}\right)$. Thus, the nitrogen cycle, which undergoes its long-term evolution, maintains the balance of nitrogen.

It is estimated that the global nitrogen fixation generates $413 \mathrm{Tg} \mathrm{N}$ every year whereas about a half, $210 \mathrm{Tg} \mathrm{N}$, comes from human activities. Furthermore, there are $100 \mathrm{Tg} \mathrm{N}$ into the atmosphere every year from the emissions of the $\mathrm{NH}_{3}$ from land and the $\mathrm{NO}_{\mathrm{x}}$ from combustion [2]. Without human activity, the 
biological nitrogen fixation and the production of $\mathrm{NO}_{\mathrm{x}}$ by lightning are the only sources for new $\mathrm{Nr}$ going into the environment [2]. Also, the estimated production of $\mathrm{NO}_{\mathrm{x}}$ by lighting is about $5 \mathrm{Tg} \mathrm{N}$ ranging from 2 to $10 \mathrm{Tg} \mathrm{N}$ every year [3-8].

Due to this variability, $\mathrm{NO}_{\mathrm{x}}$ produced by lighting would accounts for $20 \%-80 \%$ of $\mathrm{NO}_{\mathrm{x}}$ in the world [5-8]. However, the $\mathrm{NO}_{\mathrm{x}}$ produced by lighting is located in rather remote regions of the troposphere [2]. Still, other estimates indicate that the global $\mathrm{NO}_{\mathrm{x}}$ is about $40 \mathrm{Tg} \mathrm{N}$ in 2000 , of which the combustions of fossil fuel and biomass contribute to $87.5 \%$ while the emissions of soil $\mathrm{NO}$ account for $12.5 \%$ [9], i.e. each year soil microorganisms produce $9.7-21 \mathrm{Tg} \mathrm{N}$ NO $[10,11]$. In such a case, $\mathrm{NO}_{\mathrm{x}}$ produced by lighting is not particularly relevant to this estimation.

Nowadays, $\mathrm{NO}_{2}$ usually serves as the indicator for $\mathrm{NO}_{\mathrm{x}}$ because of human activity. Indeed, $\mathrm{NO}_{2}$ into the atmosphere comes primarily from the burning of fuel, including the emissions from cars, trucks and buses, power plants, and off-road equipment, although $\mathrm{NO}_{2}$ contributes about $10 \%$ of $\mathrm{NO}_{\mathrm{x}}$ and the remaining $90 \% \mathrm{NO}_{\mathrm{x}}$ is $\mathrm{NO}[11]$.

To some degree, the harmful effects of $\mathrm{NO}_{\mathrm{x}}$ to humans are mainly related to $\mathrm{NO}_{2}$. High concentrations of $\mathrm{NO}_{2}$ irritate airways in the human respiratory system. For short exposures, $\mathrm{NO}_{2}$ can aggravate respiratory diseases, especially asthma, and result in the respiratory symptoms, such as coughing, wheezing or difficulty breathing. For long exposures, $\mathrm{NO}_{2}$ may affect immune functions of respiratory system leading to potential of infections as well as asthma. Furthermore, the respiratory system can be damaged by particulate matter and ozone, which are formed during the reactions among $\mathrm{NO}, \mathrm{NO}_{2}$ and other chemicals [13]. Some studies estimated that the health damage caused by $\mathrm{NO}_{\mathrm{x}}$ emission accounted for $39 \%-47 \%$ of the relevant health damage in China [14].

Following $\mathrm{NO}_{\mathrm{x}}$ interaction with water, oxygen and other chemicals in the atmosphere, acid rain can be formed, which harms sensitive ecosystems such as lakes and forests. $\mathrm{NO}_{\mathrm{x}}$ also can form the nitrate particles, which comprise the air hazy and photochemical smog leading to low visibility, ozone and other harmful substances [15]. In the atmosphere active particles are closely related to the oxidizing capacity [16]. Still, coastal waters become nutrient enrichment due to the augmentation of air $\mathrm{NO}_{\mathrm{x}}$. The reaction of $\mathrm{NO}_{\mathrm{x}}$ with volatile organic compounds becomes an important precursor to increase the concentration of atmospheric $\mathrm{PM}_{2.5}$ [17], which also contains nitrated polycyclic aromatic hydrocarbons (NPAHs) and oxygenated polycyclic aromatic hydrocarbons (OPAHs) [18].

\section{REMOVAL OF NITROGEN OXIDES FROM THE ATMOSPHERE}

The two common methods to reduce $\mathrm{NO}_{\mathrm{x}}$ emissions are the selective catalytic reduction (SCR) and the selective non-catalytic reduction (SNCR), and SCR is considered the most widely-used method. Generally, SCR can remove around $90 \% \mathrm{NO}_{\mathrm{x}}$ from emissions whereas SNCR can remove about 30\% - 70\% $\mathrm{NO}_{\mathrm{x}}$ from emissions. In fact, the $\mathrm{NO}_{\mathrm{x}}$ removed by SCR and SNCR are the $\mathrm{NO}_{\mathrm{x}}$ that has yet to enter into the atmosphere, because both SCR and SNCR are implemented in power plans, combustion engines, etc. So there is still a certain amount of $\mathrm{NO}_{\mathrm{x}}$ passing into the atmosphere even after SCR and SNCR treatment. For example, the total emission of $\mathrm{Nr}$ in China has been doubled and the emission of $\mathrm{Nr}$ in heavily polluted areas is about 10 times of that in other areas over the last 30 years [12]. This amount of $\mathrm{NO}_{\mathrm{x}}$ actually raises the health and environmental concerns. Currently, projected regulations for $\mathrm{NO}_{\mathrm{x}}$ control in the US, EU and Asia define the limit of $\mathrm{NO}_{\mathrm{x}}$ around 30 to $200 \mathrm{mg} / \mathrm{NM}^{3}$.

It is generally considered that NO could be very slowly removed from the atmosphere through wet and dry deposition [2]. However, we would like to indicate that an important natural source to remove $\mathrm{NO}_{\mathrm{x}}$ from the atmosphere has been so far ignored. This is tobacco (Nicotiana tabacum L.), which, to the best of our knowledge, is probably the only natural source to remove $\mathrm{NO}_{\mathrm{x}}$ from the atmosphere although smoking is harmful to human health.

The top part in Figure 1 shows the overall scenario for $\mathrm{NO}_{\mathrm{x}}$ in the atmosphere, where the left-hand and right-hand sides represent the fresh air with its composition and the polluted air, respectively. The polluted air can form $\mathrm{PM}_{2.5}$ whereas the fresh air comes from removal of $\mathrm{NO}_{\mathrm{x}}$ from the atmosphere. In the 


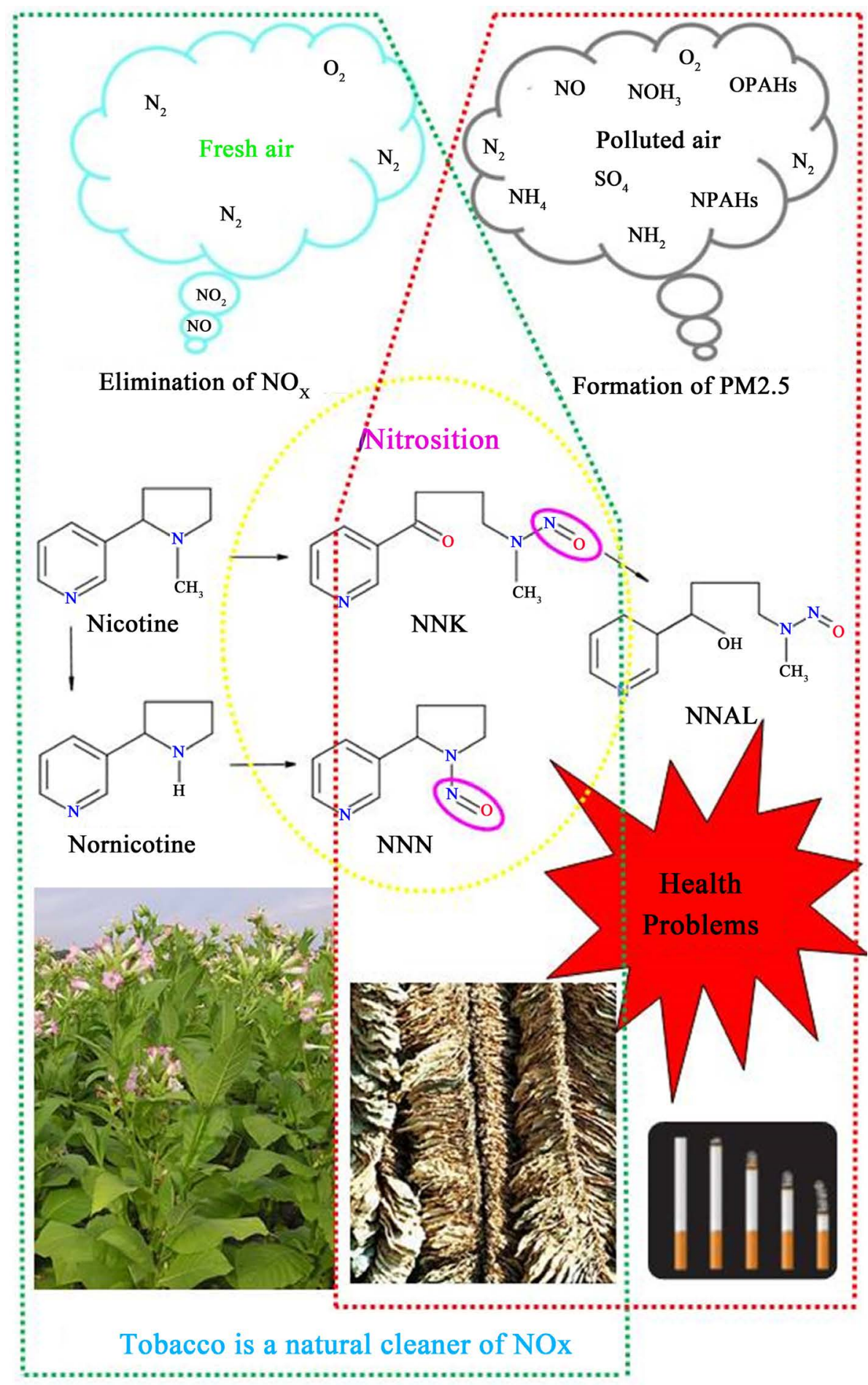

Figure 1. Tobacco's double roles in environment and human health. Yellow dashed circle indicates the nitrosation among chemical reactions in tobacco; Green dashed polygon shows tobacco effect in $\mathrm{NO}_{\mathrm{x}}$ removal from the atmosphere; Red dashed polygon demonstrates tobacco effect in health problems.

middle of Figure 1 shows how tobacco removes $\mathrm{NO}_{\mathrm{x}}$ from the atmosphere through nitrosition. There are two pathways for nitrosition, 1) nicotine can directly be nitrosated into the nicotine-derived nitrosamine ketone (NNK) [19], or 2) nicotine can be demethylated into nornicotine by P450 enzymes and then nor- 
nicotine can furthermore be nitrosated into N-nitrosonornicotine (NNN) [19]. The nitrosation for both nicotine and nornicotine requires a $\mathrm{NO}_{2}^{-}$from environments [20] (yellow dashed circle in Figure 1). Thus, tobacco helps to remove $\mathrm{NO}_{\mathrm{x}}$ from the atmosphere as indicated by green dashed polygon in the left part in Figure 1. This nitrosition occurs during tobacco leaves change from green to yellow (lower left-hand part of Figure 1) rather than during smoking (lower right-hand part of Figure 1), so tobacco plantation is helpful to remove $\mathrm{NO}_{\mathrm{x}}$ from the atomosphere. On the other hand, NNN, NNK and NNAL are carcinogenic to humans [21] as indicated by red dashed polygon in the right part of Figure 1.

The nicotine content is about $19.63 \mathrm{mg} / \mathrm{g}$ tobacco [22] because the molar weight of nicotine is 162.23 $\mathrm{g} / \mathrm{mol}$, so 1 ton tobacco would have $19.63 \mathrm{~kg}$ nicotine $(121 \mathrm{~mol})$. If all of the nicotine would be converted to NNN/NNK, then this reaction requires $5.57 \mathrm{~kg} \mathrm{NO}_{2}$ (molar weight $46 \mathrm{~g} / \mathrm{mol}$ ), i.e. one-ton tobacco can absorb $5.57 \mathrm{~kg} \mathrm{NO}_{2}$ because the reaction consumes $\mathrm{NO}_{2}^{-}$[20]. Usually, about $5 \%-20 \%$ nicotine goes to $\mathrm{NNN} / \mathrm{NNK}$ [19], then one-ton tobacco can absorb $0.28-1.10 \mathrm{~kg} \mathrm{NO}_{2}$. It is estimated that all smoked cigarettes produce 12,000 - 47,000 tons of nicotine annually yearly [23]. Accordingly, these amounts of nicotine could neutralize $171.17-670.40$ tons of $\mathrm{NO}_{2}$ in terms of $5 \%-20 \%$ nicotine goes to NNN/NNK yearly.

\section{EFFECTS OF DECREASED TOBACCO PLANTATION ON NOx REMOVAL FROM THE ATMOSPHERE}

Because of tobacco's harmful effects on humans, its plantation is actually decreasing year by year. For example, the tobacco plantation decreased from $1553 \mathrm{k}$ hectares in 2014 to $1314 \mathrm{k}$ hectares in 2015, and then further decreased to $1273 \mathrm{k}$ hectares in 2016 in China. Accordingly, the tobacco production decreased from 2,994,471 tons in 2014 to 2,832,385 tons in 2015, and then further decreased to 2,725,685 tons in 2016 [24]. In fact, the tobacco production in China was 2,839,947 tons in 2008, and was peaked in 2012 with $3,408,142$ tons. Since 2012, the tobacco production in China has been continuously decreasing and reached to 2,392,090 tons in 2017. Consequently, the removal of $\mathrm{NO}_{\mathrm{x}}$ from the atmosphere also decreased, and the un-removal of $\mathrm{NO}_{\mathrm{x}}$ should be progressively accumulated in the atmosphere because the lifetime of reactive nitrogen can range from a few weeks to few decades, even to $10^{2}-10^{3}$ years in peatlands [15].

Figure 2 displays the accumulation of $\mathrm{NO}_{\mathrm{x}}$ with reference to the reduction of tobacco production in China and the world since 2008. As can be seen, the tobacco production has begun to decrease in China since 2012 (red bars in lower panel), while the removal of $\mathrm{NO}_{\mathrm{x}}$ also has begun to drop in the atmosphere since 2012 (red and black lines in upper panel). In the rest of world, the tobacco plantation decreases from $3564 \mathrm{k}$ hectares in 2016 to $3529 \mathrm{k}$ hectares in 2017 whereas the tobacco production increases from $6,399,092$ tons in 2016 to $6,501,646$ tons in 2017 [25]. So the accumulated $\mathrm{NO}_{\mathrm{x}}$ in the atmosphere does not change significantly in contrast to China.

Due to the reduction of tobacco plantation, several hundred tons of $\mathrm{NO}_{2}$ per year are accumulating in atmosphere each year. Naturally, this amount is not big, but the accumulated amount of $\mathrm{NO}_{\mathrm{x}}$ over years would be significant. Indeed, it is not clear how many hectares of tobacco plantation have been terminated due to the harmful effects of tobacco since the industrial revolution. So arguably the accumulated $\mathrm{NO}_{\mathrm{x}}$ would be a lot. Because of the harmful effect to humans, the tobacco production would be expected to continuously reduce year by year. If the tobacco production in China will reduce $5 \%$ each year, then the accumulated $\mathrm{NO}_{\mathrm{x}}$ will reach 12,805.42 tons in 2030 (Figure 3).

Undeniably, the tobacco creates many healthy problems such as seven million people per year dying globally from tobacco use and exposure [26-28]. Also, tobacco industry creates environmental problems, i.e. deforestation $[29,30]$, cigarette butt waste [31-33]. However, these problems are created by humans rather than tobacco itself.

At this present, it is unknown how to remove $\mathrm{NO}_{\mathrm{x}}$ from the atmosphere without tobacco, and then $\mathrm{NO}_{\mathrm{x}}$ would be accumulated in the atmosphere. A point of view is that humans have no need to remove $\mathrm{NO}_{\mathrm{x}}$ from the atmosphere because $\mathrm{NO}_{\mathrm{x}}$ is useful to agriculture and fishery, and the elimination of $\mathrm{NO}_{\mathrm{x}}$ emission using the current technologies generates too much $\mathrm{CO}_{2}$ further leading to global warming [12] as the elimination of $\mathrm{NO}_{\mathrm{x}}$ consumes equal molar ammonia, whose production generates $\mathrm{CO}_{2}[34,35]$. 

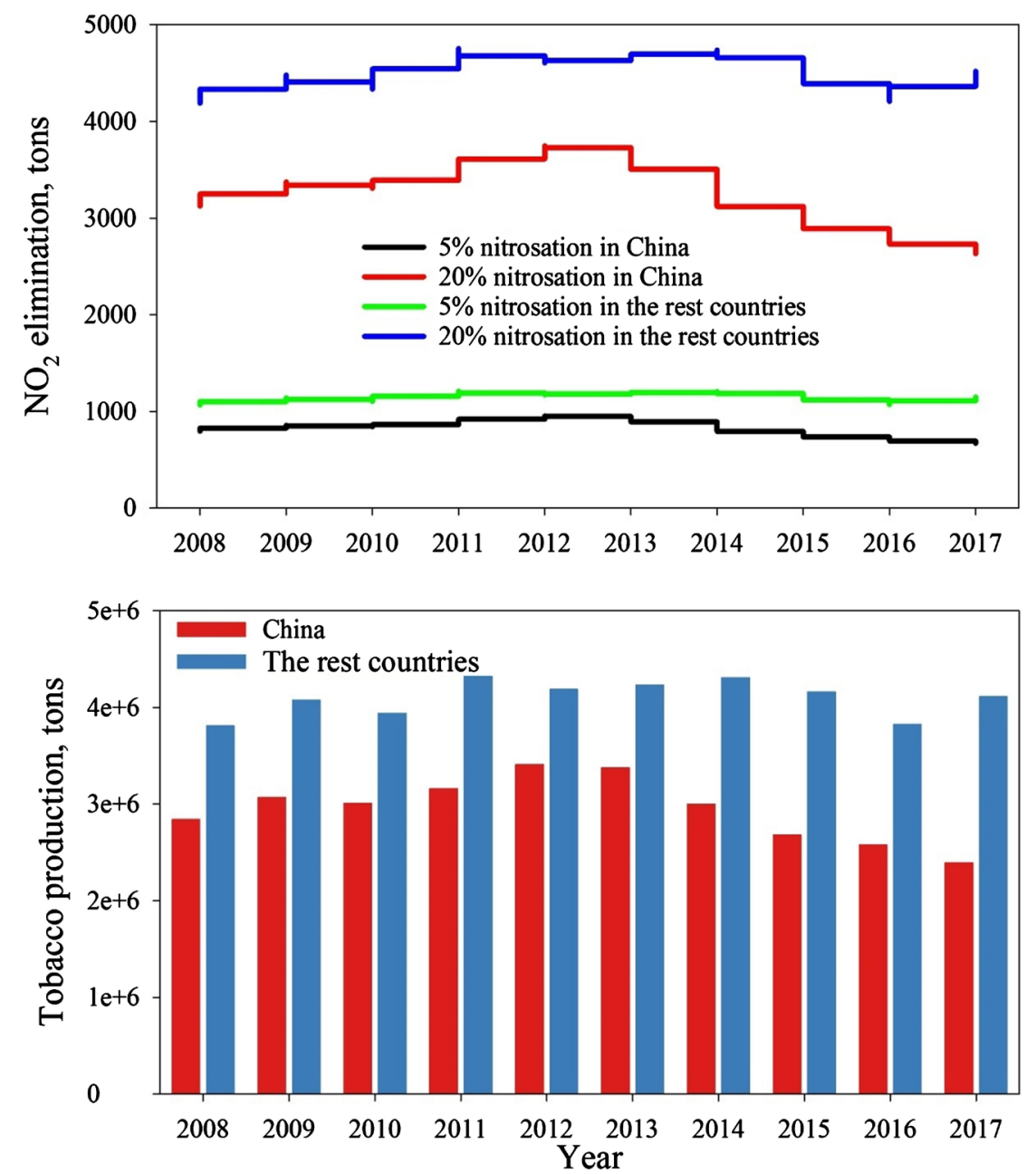

Figure 2. Tobacco production (lower panel) and related $\mathrm{NO}_{2}$ elimination from atmosphere (upper panel) in China and the rest countries from 2008 to 2017.

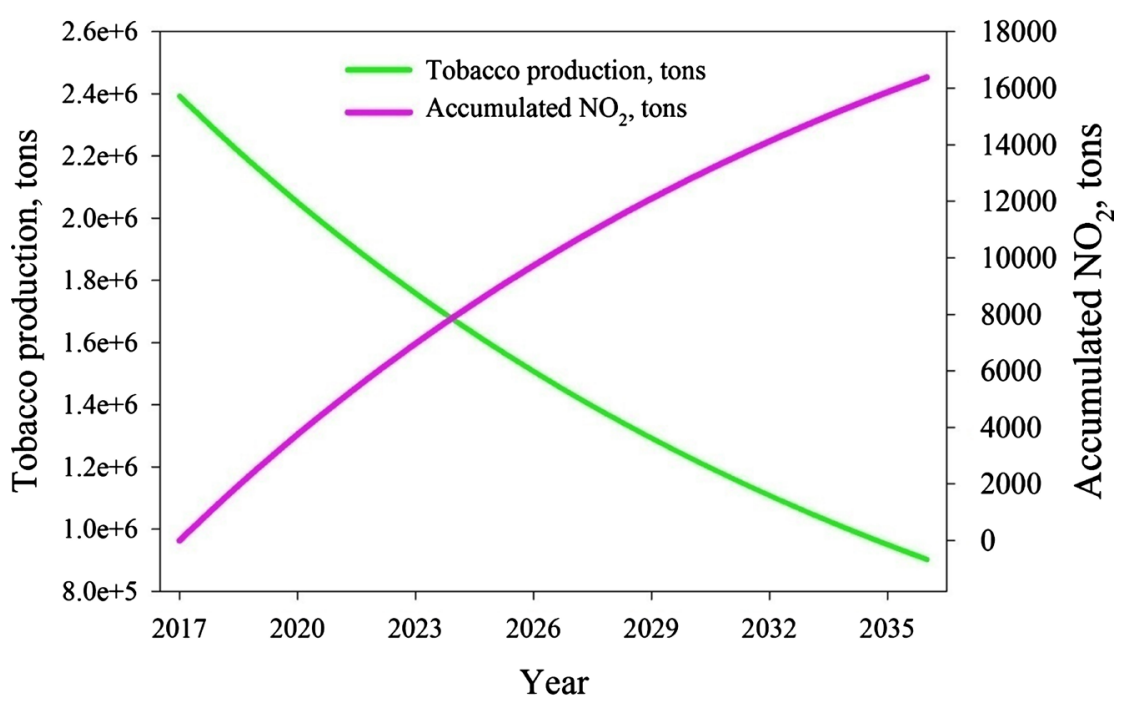

Figure 3. Predicted decrease in tobacco plantation and related accumulation of $\mathrm{NO}_{2}$ in China from 2017 to 2036. 
However, it seems not acceptable to conduct the approach not to remove $\mathrm{NO}_{\mathrm{x}}$ from atmosphere for the sake of agriculture and fishery because $\mathrm{NO}_{\mathrm{x}}$ do have well-known unhealthy effects on humans and unwanted pollution effects on environment and ecology.

\section{CONCLUSION}

Apparently, this is a dilemma: humans need to eliminate smoking for health reason through reduction of tobacco plantation, but humans also need to remove $\mathrm{NO}_{\mathrm{x}}$ from the atmosphere also for health reason. At this point, we feel tobacco innocent when humans consider it as a killer. Ecology is such a delicate system, where nature evolves various items to balance each other. In fact, tobacco plays an important role in the balance of nitrogen cycle by removing $\mathrm{NO}_{x}$, which generated by lighting, natural fire of biomass, and soil, from the atmosphere. Perhaps, we should blame ourselves, humans who use tobacco unwisely, rather than blame tobacco in nature. We are not in favor tobacco smoking, but its unique ability to remove $\mathrm{NO}_{2}$ from atmosphere should not be ignored.

\section{ETHICAL APPROVAL STATEMENT}

This article does not contain any studies with human or animal participants.

\section{ACKNOWLEDGEMENTS}

This study was supported by National Natural Science Foundation of China (31560315), and Key Project of Guangxi Scientific Research and Technology Development Plan (AB17190534).

\section{CONFLICTS OF INTEREST}

The authors declare no conflicts of interest regarding the publication of this paper.

\section{REFERENCES}

1. Stevens, C.J. (2019) Nitrogen in the Environment. Science, 363, 578-580.

https://doi.org/10.1126/science.aav8215

2. Fowler, D., Coyle, M., Skiba, U., Sutton, M.A., Cape, J.N., Reis, S., Sheppard, L.J., Jenkins, A., Grizzetti, B., Galloway, J.N., Vitousek, P., Leach, A., Bouwman, A.F., Butterbach-Bahl, K., Dentener, F., Stevenson, D., Amann, M. and Voss, M. (2013) The Global Nitrogen Cycle in the Twenty-First Century. Philosophical Transactions of the Royal Society of London. Series B, Biological Sciences, 368, 20130164. https://doi.org/10.1098/rstb.2013.0164

3. Levy, H., Moxim, W.J. and Kasibhatla, P.S. (1996) A Global Three-Dimensional Time-Dependent Lightning Source of Tropospheric $\mathrm{NO}_{\mathrm{x}}$. Journal of Geophysical Research: Atmospheres, 101, 22911-22922. https://doi.org/10.1029/96JD02341

4. Tie, X.X., Zhang, R.Y., Brasseur, G. and Lei, W.F. (2002) Global $\mathrm{NO}_{\mathrm{x}}$ Production by Lightning. Journal of Atmospheric Chemistry, 43, 61-74. https://doi.org/10.1023/A:1016145719608

5. David, A. (2005) Bridging Ocean Color Observations of the 1980s and 2000s in Search of Long-Term Trends. Journal of Geophysical Research, 110, 1-12. https://doi.org/10.1029/2004JC002620

6. Watson, W.G., Margarita, E.C., Paul, G., O'Reilly, J.E. and Nancy, W.C. (2003) Ocean Primary Production and Climate: Global Decadal Changes. Geophysical Research Letters, 30, 1809.

https://doi.org/10.1029/2003GL016889

7. Watson, W.G. and Margarita, E.C. (2002) Decadal Changes in Global Ocean Chlorophyll. Geophysical Research Letters, 29, 20-24. https://doi.org/10.1029/2002GL014689

8. Dionysios, E.R. (2005) Extending the Sea WiFS Chlorophyll Data Set Back 50 Years in the Northeast Atlantic. 
Geophysical Research Letters, 32, L06603. https://doi.org/10.1029/2005GL022484

9. van Vuuren, D.P., Bouwman, L.F., Smith, S.J. and Dentener, F. (2011) Global Projections for Anthropogenic Reactive Nitrogen Emissions to the Atmosphere: An Assessment of Scenarios in the Scientific Literature. Current Opinion in Environmental Sustainability, 3, 359-369. https://doi.org/10.1016/j.cosust.2011.08.014

10. Potter, C.S., Matson, P.A., Vitousek, P.M. and Davidson, E. (1996) Process Modeling of Controls on Nitrogen Trace Gas Emissions from Soils Worldwide. Journal of Geophysical Research, 101, 1361-1377. https://doi.org/10.1029/95JD02028

11. Davidson, E.A. and Kingerlee, W. (1997) A Global Inventory of Nitric Oxide Emissions from Soils. Nutrient Cycling in Agroecosystems, 48, 37-50. https://doi.org/10.1023/A:1009738715891

12. Ozaki, S. (2017) $\mathrm{NO}_{\mathrm{x}}$ Is Best Compound to Reduce $\mathrm{CO}_{2}$. European Journal of Experimental Biology, 7, 12. https://doi.org/10.21767/2248-9215.100012

13. US EPA (US Environmental Protection Agency) (2019) https://www.epa.gov/no2-pollution/basic-information-about-no2\#What\%20is\%20NO2

14. Gu, B., Ge, Y., Ren, Y., Xu, B., Luo, W., Jiang, H., Gu, B. and Chang, J. (2012) Atmospheric Reactive Nitrogen in China: Sources, Recent Trends, and Damage Costs. Environmental Science \& Technology, 46, 9420-9427. https://doi.org/10.1021/es301446g

15. Wayne, R.P. (1991) Chemistry of Atmospheres. 2nd Edition, Clarendon Press, Oxford, UK.

16. Isaksen, I.S.A., Granier, C., Myhre, G., Berntsen, T.K., Dalsøren, S.B., Gauss, M., Klimont, Z., Benestad, R., Bousquet, P., Collins, W., Cox, T., Eyring, V., Fowler, D., Fuzzi, S., Jöckel, P., Laj, P., Lohmann, U., Maione, M., Monks, P., Prevot, A.S.H., Raes, F., Richter, A., Rognerud, B., Schulz, M., Shindell, D., Stevenson, D.S., Storelvmo, T. Wang, W.C., van Weele, M., Wild, M. and Wuebbles, D. (2009) Atmospheric Composition Change: Climate-Chemistry Interactions. Atmospheric Environment, 43, 5138-5192. https://doi.org/10.1016/j.atmosenv.2009.08.003

17. Yan, S. and Wu, G. (2016) Network Analysis of Fine Particulate Matter $\left(\mathrm{PM}_{2.5}\right)$ Emissions in China. Scientific Reports, 6, 33227. https://doi.org/10.1038/srep33227

18. Li, J., Yang, L., Gao, Y., Jiang, P., Li, Y., Zhao, T., Zhang, J. and Wang, W. (2019) Seasonal Variations of NPAHs and OPAHs in PM2.5 at Heavily Polluted Urban and Suburban Sites in North China: Concentrations, Molecular Compositions, Cancer Risk Assessments and Sources. Ecotoxicology and Environmental Safety, 178, 58-65. https://doi.org/10.1016/j.ecoenv.2019.04.009

19. Siminszky, B., Gavilano, L., Bowen, S.W. and Dewey, R.E. (2005) Conversion of Nicotine to Nornicotine in $\mathrm{Ni}$ cotiana tabacum Is Mediated by CYP82E4, a Cytochrome P450 Monooxygenase. Proceedings of the National Academy of Sciences of the United States of America, 102, 14919-14924. https://doi.org/10.1073/pnas.0506581102

20. Lusso, M., Gunduz, I., Kondylis, A., Jaccard, G., Ruffieux, L., Gadani, F., Lion, K., Adams, A., Morris, W., Danielson, T., Warek, U. and Strickland, J. (2017) Novel Approach for Selective Reduction of NNN in Cigarette Tobacco Filler and Mainstream Smoke. Regulatory Toxicology and Pharmacology, 89, 101-111. https://doi.org/10.1016/j.yrtph.2017.07.019

21. IARC (2007) Smokeless Tobacco and Some Tobacco-Specific N-Nitrosamines. In: International Agency for Research on Cancer (Ed.), IARC Monographs on the Evaluation of Carcinogenic Risks to Humans. World Health Organization, Lyon, France.

22. O’Connor, R.J., Schneller, L.M., Caruso, R.V., Stephens, W.E., Li, Q., Yuan, J. and Fong, G.T. (2015) Toxic Metal and Nicotine Content of Cigarettes Sold in China, 2009 and 2012. Tobacco Control, 24, iv55-iv59. https://doi.org/10.1136/tobaccocontrol-2014-051804 
23. Novotny, T.E., Bialous, S.A., Burt, L., Curtis, C., da Costa, V.L., Iqtidar, S.U., Liu, Y., Pujari, S. and Tursan d'Espaignet E. (2015) The Environmental and Health Impacts of Tobacco Agriculture, Cigarette Manufacture and Consumption. Bulletin of the World Health Organization, 93, 877-880.

https://doi.org/10.2471/BLT.15.152744

24. (2019) Statistics from Ministry of Agriculture and Rural Affairs of the People's Republic of China. http://zdscxx.moa.gov.cn:8080/misportal/public/publicationRedStyle.jsp

25. Food and Agriculture Organization of the United Nations. (2019) http://www.fao.org/faostat/en/\#data/QC/visualize

26. Ng, M., Freeman, M.K., Fleming, T.D., Robinson, M., Dwyer-Lindgren, L., Thomson, B., Wollum, A., Sanman, E., Wulf, S., Lopez, A.D., Murray, C.J. and Gakidou, E. (2014) Smoking Prevalence and Cigarette Consumption in 187 Countries, 1980-2012. JAMA, 311, 183-192. https://doi.org/10.1001/jama.2013.284692

27. GBD 2015 Tobacco Collaborators (2017) Smoking Prevalence and Attributable Disease Burden in 195 Countries and Territories, 1990-2015: A Systematic Analysis from the Global Burden of Disease Study 2015. Lancet, 389, 1885-1906. https://doi.org/10.1016/S0140-6736(17)30819-X

28. World Health Organization (2017) WHO Report on the Global Tobacco Epidemic, 2017: Monitoring Tobacco Use and Prevention Policies. WHO, Geneva.

29. Otañez, M.G., Mamudu, H.M. and Glantz, S.A. (2009) Tobacco Companies' Use of Developing Countrie' Economic Reliance on Tobacco to Lobby against Global Tobacco Control: the Case of Malawi. The American Journal of Public Health, 99, 1759-1771. https://doi.org/10.2105/AJPH.2008.146217

30. Otañez, M. and Glantz, S.A. (2011) Social Responsibility in Tobacco Production? Tobacco Companies' Use of Green Supply Chains to Obscure the Real Costs of Tobacco Farming. Tobacco Control, 20, 403-411. https://doi.org/10.1136/tc.2010.039537

31. Novotny, T.E., Lum, K., Smith, E., Wang, V. and Barnes, R. (2009) Cigarettes Butts and the Case for an Environmental Policy on Hazardous Cigarette Waste. International Journal of Environmental Research and Public Health, 6, 1691-1705. https://doi.org/10.3390/ijerph6051691

32. Healton, C.G., Cummings, K.M., O'Connor, R.J. and Novotny, T.E. (2011) Butt Really? The Environmental Impact of Cigarettes. Tobacco Control, 20, i1. https://doi.org/10.1136/tc.2011.043729

33. Curtis, C., Collins, S., Cunningham, S., Stigler, P. and Novotny, T.E. (2014) Extended Producer Responsibility and Product Stewardship for Tobacco Product Waste. International Journal of Waste Resources, 4, 157.

34. Chambers, J.Q., Higuchi. N., Tribuzy, E.S. and Trumbore, S.E. (2001) Carbon Sink for a Century. Nature, 410, 429. https://doi.org/10.1038/35068624

35. Fourqurean, J.W., Duarte, C.M., Kennedy, H., Marba, N. and Holmer, M. (2012) Seagrass Ecosystems as a Globally Significant Carbon Stock. Nature Geoscience, 5, 505-509. https://doi.org/10.1038/ngeo1477 